\title{
Discipline of Fitness Members in the Adaptation of New Habits in Buleleng Regency
}

\author{
Made Agus Wijaya ${ }^{1, *}$, Putu Panca Adi ${ }^{1}$, Kadek Yogi Parta Lesmana ${ }^{1}$ \\ ${ }^{1}$ Physical Education, Health and Recreation Study Program, Universitas Pendidikan Ganesha, Singaraja, Indonesia \\ *Corresponding author.Email: wijaya.madeagus@undiksha.ac.id
}

\begin{abstract}
Physical activity still needs to be carried out during the Covid-19 pandemic to keep the body healthy and fit. One of the physical activities carried out by Buleleng people is fitness. The purpose of this study was to obtain empirical data regarding the level of discipline of fitness members during the period of adaptation of new habits in Buleleng Regency. This descriptive study utilized simple random sampling with a total sample of 99 people. The research instrument was a closed questionnaire in the form of a google form. The data were analyzed using qualitative descriptive technique. The results showed that: $49(49.49 \%)$ fitness members were categorized as very disciplined, 38 (38.38\%) fitness members were categorized as disciplined, $11(11.11 \%)$ fitness members were categorized as moderately disciplined, and 1 person $(1.01 \%)$ was categorized as lack of discipline. Based on the data analysis and discussion, the conclusion of this study is that the discipline of fitness members during the period of adaptation of new habits in Buleleng Regency was categorized as discipline. It is recommended to the people of Buleleng Regency to continue to carry out physical activities by implementing strict health protocols.
\end{abstract}

Keywords: Discipline, Covid, Fitness.

\section{INTRODUCTION}

The Covid-19 pandemic in Bali Province at the beginning of 2021 had a tendency to continue to increase. The latest data released on February 23, 2021 by the Government of Bali Province stated that the cumulative number of cases of Balinese confirmed positive of Covid-19 was 33,077 people, comprised of those who recovered as many as 29,830 people (90.18\%), and died as many as 891 people $(2.69 \%)$, where the addition of active cases per day reached 2,356 people (7.12\%). Likewise, in Buleleng Regency, the data taken from the Covid-19 Task Force of Buleleng Regency recorded that 2,250 Buleleng people were confirmed positive, where 1,965 people recovered (87.33\%), 192 people were in treatment $(8.53 \%)$ and 93 people died. $(4.13 \%)$.

Various efforts have been made by the Government of Bali Province and the Government of Buleleng Regency to suppress and reduce the increase in the development of Covid-19 from the issuance of the Regulation of Bali Governor No. 46 of 2020 concerning the Implementation of Discipline and Law Enforcement of Health Protocols as an Effort for Prevention and Control of Corona Virus Disease 2019, the implementation of restrictions on social activities (PPKM) [1] up to the implementation of the adaptation of new habits/AKB [2]. Through AKB, the government recommends carrying out sport activities as a means to increase body's immunity in addition to getting adequate rest and meeting a balanced nutritional intake pattern.

From September to October 2021, the Covid-19 pandemic in Bali Province tended to see a decrease. The latest data on Sunday, October 1, 2021 recorded that the number of cases of Balinese people who were confirmed positive for Covid-19 was 61 people, patients recovered as many as 86 people and died as many as 2 people. Likewise, in Buleleng Regency, the data from the Covid-19 Task Force of Buleleng Regency recorded that the addition of positive confirmed cases was only 1 person and 7 people recovered. The decline of COVID19 cases has implication for the re-opening of schools through limited and conditional face-to-face meetings, limited opening of malls and shopping centers, Ngurah Rai airport accepting international arrivals and limited opening of infrastructure and green open spaces.

The people of Buleleng Regency began to carry out daily activities although still with some restrictions, students began to attend school with strict monitoring 
from the school and related authorities, and fitness centers such as gyms and gymnastics studios began to open as well.

Fitness exercises, especially at the gyms/fitness centers in Buleleng Regency, are activities that are currently in demand and carried out in an effort to maintain body immunity during the current Covid-19 pandemic. These fitness exercises ideally apply strict health protocols to stay healthy and fit. However, until presently, there has been no empirical data on the level of discipline of fitness exercises during the adaptation period of new habits/AKB in Buleleng Regency. Therefore, this research was deemed very urgent to be carried out.

Discipline is a condition that is created and formed through a process and a range of attitudes that show the values of obedience, compliance, order, and orderliness. Discipline comes from the English word 'discipline' which means "training to act in accordance with rules," training someone to act according to the rules [3]. Discipline as an attitude of honor, respect, obedience, and compliance to the applicable regulations, both written and unwritten and the ability to perform such attitude and to not avoid receiving sanctions upon violating the given duties and authorities [4]. Discipline is an attitude of respecting and appreciating an applicable regulation, both written and unwritten and being able to carry it out and not refusing to accept sanctions if he violates the duties and authorities given to him [5].

According to [6] discipline is a controlled and regulated human behavior and is based on the awareness as well as noble intentions of the person concerned so that his existence is always happy for himself and others [6]."

Discipline is an aspect of the socialization process that directs individuals to meet/obey what is expected of their environment (family, school, and community) from it.

The Government of Indonesia through the Ministry of Health has provided guidelines in adapting new habits/AKB to exercise by observing the updated information about covid-19, avoiding direct physical contact, wearing masks, using hand sanitizer, washing hands, maintaining safe distance, avoiding touching face area, bathing, and changing clothes after exercise as well as always cleaning the exercise equipment. In addition, the Indonesian Ministry of Health specifically provides guidelines for physical exercise for members of the fitness centers/gyms [7].

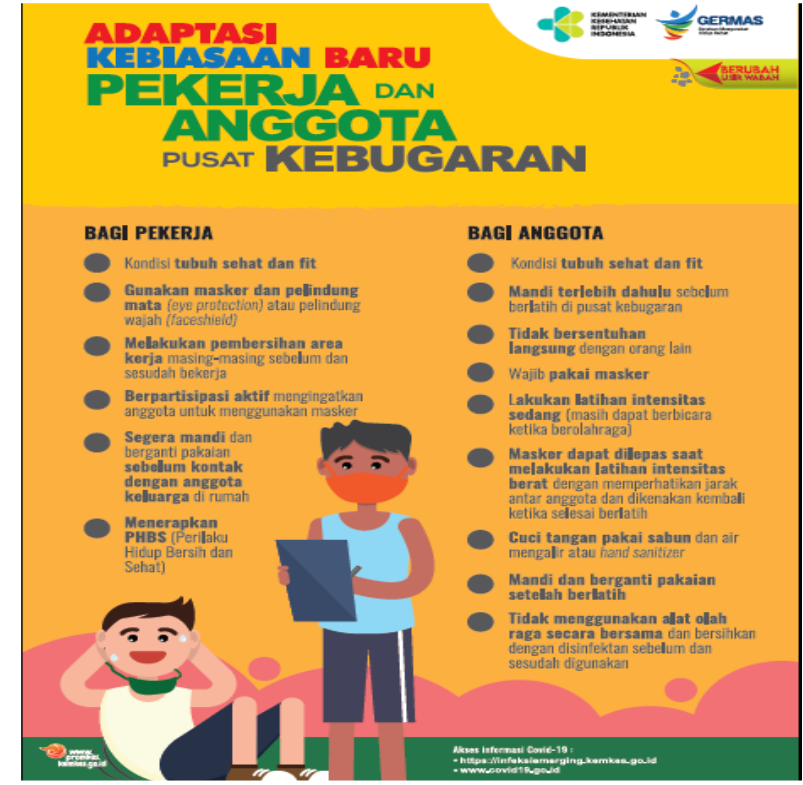

Figure 1. Adaptation of New Habits of exercise for the members of the fitness center

Source: Ministry of Health of the Republic of Indonesia (2020)

\section{METHODS}

Based on the studied problems, this research is classified as descriptive research. Descriptive research is research conducted to describe certain symptoms, phenomena, or events. Data collection was carried out to obtain information related to certain phenomena, conditions, or variables and was not intended to test hypotheses. [8] state: “... descriptive research is not generally directed toward hypothesis testing. The aim to describe 'what exists' with respect to variables or conditions in situation" [8]. According to [9], descriptive research is not intended to test certain hypotheses, but only to describe a variable, symptom, or situation as it is [9].

In line with the above statement, Reference [10] states that descriptive research is a study that intends to describe a phenomenon/event systematically as it is [10]. Furthermore, Nyoman Dantes states that the types of descriptive research include case studies, surveys, developmental studies, follow-up studies, documentary analysis, trend analysis and correlation studies. This descriptive research is categorized as sample survey research, because data collection is only carried out on a portion of the population.

\subsection{Selecting Sample of the Study}

The population of this research consisted of the members of the fitness centers in Buleleng Regency, an estimated of 150 people. The number of research samples was 99 people, using simple random sampling with the following criteria: 1) male and female, 2) 
minimum age of 17 years, and 3) active in sports in the last 2 months. The samples of the research performed exercise at the Victory Gym club, Bali Arta Fitness and Matrix Gym.

\subsection{Instrument of the Study}

The research instrument used in this study was in the form of test and non-test. The test referred to in this research was the provision of questionnaire on the level of discipline of the fitness members in Buleleng Regency in the form of google form. Meanwhile, the non-test form was in-depth interviews of the researchers with the fitness members and managers to complete the data that was not summarized in the questionnaire and to ensure the validity of the data with the daily reality of the fitness members in Buleleng Regency. The research instrument used in this research has met the face validity, which was validated by experts, namely Dr. I Wayan Artanayasa, S.Pd.,M.Pd and Dr. dr. Made Kurnia Widiastuti Giri, S.Ked., M.Kes, who have more than 10 years of teaching experience and educator certificate.

The questionnaire in the form of google form consisted of 26 items of positive and negative statements. The criteria for the discipline level of fitness members were as listed in the table 1 .

\section{RESULT AND DISCUSSION}

\subsection{Result}

Respondents of fitness members who actively participated in filling out the questionnaire were 99 people, consisting of 11 (11\%) women and $88(89 \%)$ men. Based on the age of the respondents, the number of fitness members who filled out the questionnaire is listed in table 2.

Table 1. Criteria For Discipline Level of The Fitness Members in Buleleng Regency, Bali

\begin{tabular}{|c|c|}
\hline Score Range & Category \\
\hline 104 and above & Very Disciplined \\
\hline $87-103$ & Disciplined \\
\hline $69-86$ & Moderately Disciplined \\
\hline $52-68$ & Lack of Discipline \\
\hline below 52 & Very Lack of Discipline \\
\hline
\end{tabular}

Table 2. Age Of Respondents of The Fitness Members in Buleleng Regency, Bali

\begin{tabular}{|c|c|c|}
\hline Age & Number & Percentage \\
\hline $17-22$ years old & 70 people & $71 \%$ \\
\hline
\end{tabular}

\begin{tabular}{|c|c|c|}
\hline $23-28$ years old & 10 people & $10 \%$ \\
\hline $29-34$ years old & 2 people & $2 \%$ \\
\hline $35-40$ years old & 8 people & $8 \%$ \\
\hline 41 years old and above & 9 people & $9 \%$ \\
\hline & 99 people & $100 \%$ \\
\hline
\end{tabular}

Table 3. Exercise Frequency Per Week The Of Fitness Members in Buleleng Regency, Bali

\begin{tabular}{|c|c|c|}
\hline Frequency & Number & Percentage \\
\hline 1 time & 13 people & $13 \%$ \\
\hline 2 times & 23 people & $23 \%$ \\
\hline 3 times & 28 people & $28 \%$ \\
\hline 4 times & 19 people & $19 \%$ \\
\hline More than 4 times & 16 people & $16 \%$ \\
\hline & 99 people & $100 \%$ \\
\hline
\end{tabular}

Based on table II, it can be seen that respondents aged 17-22 years filled out the most questionnaires, reaching up to 70 people $(71 \%)$, followed by respondents aged 23-28 years as many as 10 people $(10 \%)$, respondents aged 41 years and above as many as 9 people (9\%), aged $35-40$ years reached 8 people $(8 \%)$ and 2 respondents (2\%) aged 29-34 years.

Based on the frequency of fitness exercise per week, the research data obtained as shown on table 3.

As referred to Table III, it can be seen that the frequency of fitness exercise that was most often done by the respondents was 3 times per week with a total of 28 respondents $(28 \%)$, followed by 2 times per week as many as 23 people (23\%), 4 times per week as many as 10 people $(19 \%)$, more than 4 times per week as many as 16 people (16\%) and 1 time per week as many as 13 respondents $(13 \%)$.

In addition to data on sex, age, and frequency of fitness exercise per week, this research obtained data that 93 people (94\%) fitness exercisers in Buleleng Regency had participated in the covid 19 vaccination program, while 6 people $(6 \%)$ had not participated in the vaccination on the grounds that they had not been scheduled for vaccination, some of them had comorbidities (hypertension, diabetes, heart) and fear of needles.

The level of discipline of the members of the fitness centers in Buleleng Regency is shown in Figure 2. 


\section{Tingkat Kedisiplinan Pengolahraga Fitness \\ $11 ;$
$11 \%$

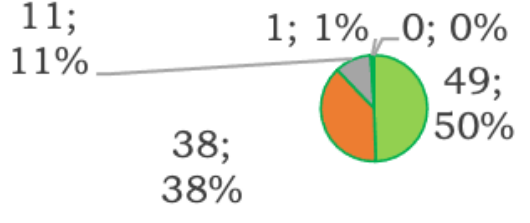 \\ $\square$ Sangat Disiplin $\square$ Disiplin $\quad \square$ Cukup Disiplin \\ $\square$ Kurang Disiplin $\square$ Sangat Kurang}

Figure 2 The Discipline Level of the Fitness Members in Buleleng Regency, Bali

Based on Figure 2, it can be seen that the level of discipline of fitness exercisers in Buleleng Regency was the highest in the very disciplined category, reaching 49 respondents (50\%), followed by the disciplined category with 38 people (38\%), moderately disciplined category reaching 11 people, $(11 \%)$ and lack of discipline category with only 1 person (1\%).

Based on the data analysis, the mean of the discipline level of the fitness exercisers in Buleleng Regency, Bali reached a score of 102 out of a maximum score of 130 , which was categorized as discipline.

\subsection{Discussion}

The Covid-19 pandemic, which has hit almost the entire world, has become the focus of the government of every country to reduce the number of people infected with the COVID-19 virus. The Government of the Republic of Indonesia has been paying a great attention to tackling this pandemic through the covid 19 vaccination program, more intensive socialization of $3 \mathrm{M}$, the application of centralized isolation for People Without Symptoms/OTG to restricting social activities known as the Enforcement of Restrictions on Social Activities/PPKM.

The global condition of the COVID-19 pandemic has certainly forced people to adapt and even live side by side with Covid-19. The COVID-19 pandemic has caused an abrupt change in lifestyle for many people with restrictions, often leading to a decrease in physical activity (PA), and thus contributing to a negative perception of health status [11]. Reference [12] wrote in their article, the opportunity for physical activity in the Australian State of Victoria during the COVID-19 pandemic is strictly limited, physical fitness centers/gyms, swimming pools and community-based sports centers are closed. Furthermore reference [12] state that the inability of the society to be actively involved in routine physical activities is a source of public frustration. For this reason, government roles and policies are urgently needed to facilitate preventive efforts by promoting active community involvement in carrying out enjoyable physical [13].

Indonesian people have been encouraged to continue to carry out physical activities by implementing strict health protocols. One of the physical activities carried out is fitness exercise in the fitness center/gym. Various gym service providers have certain strategies to attract the public to use gym services. According [14], the development of physical fitness centers (gyms) in South Korea has been increasing as a result of market expansion and increased services provided to customers so that customer satisfaction is maintained.

Furthermore reference [15], conclude that the availability and completeness of equipment, environment, accessibility, and membership fees are the main factors that South Korean people choose to become members of a fitness center/gym. The availability and comprehensiveness of the fitness center include the up-to-date fitness equipment provided by the gym manager and the various and adequate amounts and types of equipment used by customers at the fitness center. There are at least 3 things in the fitness environment that need attention, namely: 1) availability and management of storage areas (lockers) and showers, 2) cleanliness of the fitness room and surrounding area, and 3) availability and adequacy of space for movement. The membership fee is affordable by the customers and the commute time to the physical fitness center/gym by public transportation is no more than 30 minutes.

Referring to the results of this research, the level of discipline of fitness members in Buleleng Regency-Bali was categorized as disciplined, this can also be seen during direct observations of the researchers at the fitness centers in Buleleng Regency at Victory Gym club, Bali Arta Fitness and Matrix Gym. Fitness center managers and fitness members worked together to maintain and implement strict Health protocols. Fitness members followed health data collection procedures starting from identifying being sick with coughing, or increasing body temperature, wearing masks, measuring body temperature, washing hands before entering the fitness room, maintaining a safe distance during activities, and using hand sanitizers. After fitness exercises, the members immediately went back home, showered, and changed clothes. It is believed that with strict health protocols, balanced nutrition/nutrition intake patterns and quality rest, good physical fitness related to health/physical fitness and skills/motor fitness will be maintained [16].

According to reference [17], experts and the government advise during covid 19 to keep the body in shape by exercising at home using various safe, simple, and easy ways to do it. Exercise is suitable for avoiding contact with crowds and keeping improving fitness. These forms of exercise include strengthening exercises for balance and control and stretching exercises. 
The fitness centers managers always checked the behavior of the fitness members at the fitness centers/gyms, if there were crowds, the room supervisor would remind them to maintain their distance again, and the manager provided a thermogun as a body temperature detector, provided a place to wash hands and hand soap, hand sanitizer. and routinely sprayed disinfectant in the room to sterilize the fitness room.

The synergy between fitness centers/gyms managers and fitness members in implementing strict Health protocols during the Covid-19pandemic has increased the confidence of fitness members to continue to carry out physical activities at the fitness center without worry. This also actualized the government's policy to continue carrying out physical activities as part of the new adaptation of sports activities during the pandemic.

New habits for a healthier life must be continuously carried out in society and every individual, so that it becomes a new social norm and individual norm in everyday life. Thus, we can work, study, worship and other activities safely, healthy and productively. The adaptation of new habits in question are: wash your hands frequently with soap, wear a mask, maintain a distance, adequate rest and diligent exercise, and eat a balanced nutritious diet. It's time to be a pioneer in adapting new habits [18].

Various movement activities were carried out during the adaptation of new habits period, according to reference [19] yoga during the adaptation of new habits period was able to improve physical and mental health in children. Yoga is done with fun because children are invited to play, develop their imagination in doing yoga postures. Likewise, during this pandemic, family resilience is needed, especially in the face of isolation from being exposed to Covid-19. The results of [20] state that family emotional reactions (positive and negative) appear related to the resilience of their families during the Covid-19 isolation period

\section{CONCLUSION}

Based on the data analysis and discussion, this study concludes that the level of discipline of fitness members in Buleleng-Bali was categorized as disciplined. The discipline of fitness members as well as the synergy of the fitness centers/gyms managers in implementing strict health protocols during the COVID-19 pandemic has also realized the government's policy to continue to carry out physical activities as part of the new adaptation of sports activities during the pandemic.

\section{ACKNOWLEDGMENTS}

The researchers would like to extend gratitude and appreciation to the Rector of Ganesha University of
Education who was willing to finance this study and we gratefully thank and feel proud of the hard work and commitment of the managers and members fitness centers in Buleleng regency who actively participated during this research.

\section{REFERENCES}

[1] P. Bali, Perpanjangan Pemberlakuan pembatasan kegiatan masyarakat berbasis Desa/Kelurahan dalam tatanan kehidupan era baru di Provinsi Bali. Indonesia, 2011.

[2] P. Bali, Penerapan Disiplin dan Penegakan Hukum Protokol Kesehatan Sebagai Upaya Pencegahan dan Pengendalian Corona Virus Disease 2019 dalam Tatanan Kehidupan Era Baru. Indonesia, 2020

[3] U. Wirantasa, "Pengaruh Kedisiplinan Siswa terhadap Prestasi Belajar Matematika," J. Form., vol. 7, no. 1, pp. 83-95, 2017.

[4] S. Sastrohadiwiryo, Manajemen Tenaga Kerja Indonesia. Jakarta: Bumi Aksara.

[5] M. S. Hasibuan, Manajemen Sumber Daya Manusia. Jakarta: Bumi Aksara, 2002.

[6] Unarajan and Dolet, Manajemen Disiplin. Jakarta: PT. Grasindo, 2003.

[7] K. RI, "Adaptasi Kebiasaan Baru Berolahraga," 2020 .

[8] D. Ary, L. Jacobs, and A. Razavieh, Introduction to Research in Education. Harcourt Brace College Publisher, 1900.

[9] S. Arikunto, Prosedur Penelitian. Jakarta: Rineka Cipta, 2010.

[10] N. Dantes, Metode Penelitian. Yogyakarta, 2012.

[11] M. Hyuma and Et.al, "Physical Activity and Perceived Physical Fitness during the COVID-19 Epidemic: A Population of 40- to 69-Year-Olds in Japan," Int. J. Environ. Res. Public Heal. Int. J. Environ. Res. Public Heal., vol. 18, 2021, doi: https://doi.org/10.3390/ ijerph18094832.

[12] Barret, Sephen, K. Rodda, S. Begg, P. D. O'Halloran, and M. Kingsley, "Exercise and Covid-19: Reasons Individual sought Coaching Support to Assist them to Increase Physical Activity during Covid-19," Aust. New Zel. J. Public Heal., vol. 45, no. 2, 2021, doi: 133137.DOI:10.1111/1753-6405.13089.

[13] A. Vatter and W. Bartl, "Justifying Physical Activity (Dis-)Engagements: Fitness Centers and the Latent Expectations of (Former) Members,' 
Hist. Soc. Res., vol. 46, no. 1, pp. 181-205, 2021, doi: 10.12759/hsr.46.2021.1.181-205.

[14] Y. Choi, "A Theoretical Study on Relationship Marketing of Fitness center," J. Sport Leis. Stud., vol. 68, pp. 47-63, 2017.

[15] W. Y. Jang and K. Choi, "Factors Influencing Choice when Enrolling at a Fitness Center. Social Behavior and Personality," Sci. J. Publ. Ltd., vol. 46, no. 6, pp. 1043-1056, 2018.

[16] R. Lutan, Olahraga dan Etika Fair Play. Jakarta: Depdiknas-Ditjora, 2002.

[17] N. Susanto, "Pengaruh Virus Covid 19 terhadap Bidang Olahraga di Indonesia," J. Stamina Pasca Sarj. Univ. Negeri Padang, vol. 3, no. 3, 2020.

[18] T. Irawati, "Menuju Adaptasi Kebiasaan Baru. Direktorat Promosi Kesehatan dan Pemberdayaan Masyarakat Kementerian Kesehatan Republik Indonesia," Jakarta, 2020.

[19] I. Sofiyanti, F. P. Astuti, and H. Setyowati, "Meningkatkan Kesehatan Fisik dan Kesehatan Mental Anak dengan Yoga di Masa Adaptasi Kebiasaan Baru," Indones. J. Community Empower., 2020.

[20] M. R. Ramadhana, "Memperkuat ketahanan keluarga selama Adaptasi kebiasaan baru di masa pandemik COVID-19," J. Kependud. Indones., vol. 61, no. 6, 2020. 